J. Clin. Chem. Clin. Biochem.

Vol. 17, 1979, pp. 773-775

\title{
Cholesterol in High-Density Lipoproteins: A Comparison Between Dextran Sulfate-Magnesium Chloride Precipitation and Preparative Ultracentrifugation
}

By $P$. Weisweiler,

\section{2nd Medical Clinic, Klinikum Grosshadern, University of Munich}

\section{B. Schottdorf,}

Augsburg,

and $P$. Schwandt,

2nd Medical Clinic, Klinikum Grosshadern, University of Munich

(Received March 17/August 3, 1979)

Summary: The cholesterol in high density lipoproteins (HDL) has been determined in 140 serum samples after dextran sulfate-magnesium chloride precipitation of the apolipoprotein B-containing lipoproteins. The values correlated well with simultaneously measured values from preparative ultracentrifugation (slope $0.98, r=0.93$ ). Furthermore, there was a significant correlation in 60 specimen between the dextran sulfate- $\mathrm{MgCl}_{2}$ and heparin- $\mathrm{MnCl}_{2}$-precipitation method.

Dextran sulfate- $\mathrm{MgCl}_{2}$ precipitation allows a precise and reproducible HDL-cholesterol determination (CV from 20 days $2.7 \%$ ).

Cholesterin in Lipoproteinen hoher Dichte: Ein Vergleich zwischen Dextransulfat-Magnesiumchloridpräzipitation und präparativer Ultrazentrifugation

Zusammenfassung: Das Cholesterin in Lipoproteinen hoher Dichte (HDL) wurde in 140 Proben nach DextransulfatMagnesiumchlorid-Fällung der Apolipoprotein B-hältigen Lipoproteine bestimmt. Die gemessenen Werte korrelierten gut mit den gleichzeitig bestimmten Werten von der präparativen Ultrazentrifuge (Anstieg der Korrelationsgerade 0,98, $\mathrm{r}=$ 0,93). Es bestand ebenfalls eine signifikante Korrelation in 60 Proben zwischen der Dextransulfat- $\mathrm{MgCl}_{2}-$ und $\mathrm{Heparin}$ $\mathrm{MnCl}_{2}$-Methode $(1,03, \mathrm{r}=0,95)$.

Mit Dextransulfat- $\mathrm{MgCl}_{2}$ ist eine präzise und reproduzierbare HDL-Cholesterinbestimmung möglich (VK von 20

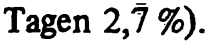

\section{Introduction}

$\mathrm{HDL}^{\mathbf{1}}$ ) cholesterol concentration is inversely associated with the incidence of atherosclerotic coronary heart disease $(1-4)$. Common methods for measuring HDL cholesterol are based on polyanion precipitation of the lipoproteins that contain apolipoprotein B. Most of the investigations were performed with heparin-manganese chloride, and the resulting values showed a good correl-

$1 \mathrm{VLDL}=$ very low density lipoproteins, $\mathrm{LDL}=$ low density lipoproteins, $\mathrm{HDL}=$ high density lipoproteins. ation with ultracentrifugal HDL cholesterol values $(5,6,7)$. Other methods, using dextran sulfate, or sodium phosphotungstate and magnesium chloride, may be simpler $(8,9)$. Furthermore, the use of $\mathrm{MnCl}_{2}$ has been criticized because it results in the production of complexes (10).

To our knowledge there are two reports concerning the high precision and specificity of the dextran sulfate method $(8,9)$. The correlation with HDL cholesterol values after preparative ultracentrifugation has not been reported. We therefore determined HDL cholesterol 
Tab. 1. Linear regression analysis: $\mathrm{HDL}$ cholesterol, ultracentrifugation versus dextran-sulfate- $\mathrm{MgCl}_{2}$ precipitation and dextran sulfate- $\mathrm{MgCl}_{2}$ precipitation versus heparin- $\mathrm{MnCl}_{2}$ precipitation. $X \mathrm{p}<0.001$.

\begin{tabular}{|c|c|c|c|c|c|}
\hline & $\mathrm{n}$ & $\begin{array}{l}\text { Cholesterod } \\
(\mathrm{mmol} / \mathrm{l}) \\
\overline{\mathbf{x}} \pm \mathrm{s}_{\bar{x}}\end{array}$ & Slope & $\begin{array}{l}\text { Linear reg } \\
\text { y-intercep }\end{array}$ & $\begin{array}{l}\mathrm{n} \text { analysis } \\
\mathrm{r} \pm \mathrm{SD}\end{array}$ \\
\hline HDL-cholesterol & 140 & & 0.98 & 2.86 & $0.93 \pm 0.03^{x}$ \\
\hline $\begin{array}{l}\text { Ultracentrifugation } \\
\text { Dextran sulfate- } \mathrm{MgCl}_{2} \text { precipitation }\end{array}$ & & $\begin{array}{l}1.19 \pm 0.03 \\
1.14 \pm 0.03\end{array}$ & & & \\
\hline HDL-cholesterol & 60 & & 1.03 & -0.389 & $0.95 \pm 0.05^{x}$ \\
\hline $\begin{array}{l}\text { Heparin- } \mathrm{MnCl}_{2} \text { precipitation } \\
\text { Dextran sulfate- } \mathrm{MgCl}_{2} \text { precipitation }\end{array}$ & & $\begin{array}{l}1.19 \pm 0.05 \\
1.16 \pm 0.05\end{array}$ & & & \\
\hline
\end{tabular}

simultaneously with these two methods, and compared the results with those obtained with the heparin- $\mathrm{MnCl}_{2}$ precipitation method.

\section{Material and Methods}

Serum samples were obtained from 140 adults (mean age \pm SEM $49 \pm 3$ years) after an overnight fast. Most of the subjects $(n=112)$ were hyperlipoproteinemic outpatients. Values for serum total cholesterol ranged from 3.04 to $20.54 \mathrm{mmol} / \mathrm{l}$ and for serum triglycerides from 0.94 to $71.78 \mathrm{mmol} / \mathrm{l}$. The fractionation of serum lipoproteins by preparative ultracentrifugation at densities $\mathrm{d}<1.006 \mathrm{~g} / \mathrm{ml}$ (VLDL separation) and $\mathrm{d}<1.063 \mathrm{~g} / \mathrm{ml}$ (LDL separation, HDL determination in the bottom fraction) was performed for all samples as described earlier $(11,12)$. The recovery of lipoprotein lipids in VLDL, LDL and HDL was always within $100 \pm 10 \%$ of total serum cholesterol.

For the separation of $\mathrm{HDL}$ by dextran sulfate- $\mathrm{MgCl}_{2}$ precipitation the method of Kostner (8) was used: $1 \mathrm{ml}$ of serum was mixed with $50 \mu \mathrm{l}$ of $\mathrm{MgCl}_{2}$ solution $(2 \mathrm{~mol} / \mathrm{l})$ and $50 \mu \mathrm{l}$ of a dextran sulfate 500 solution $(20 \mathrm{~g} / \mathrm{l}$, Pharmacia, Uppsala, Sweden), allowed to stand for 5 minutes, and centrifuged ( $5000 \mathrm{~g}$ $30 \mathrm{~min}$ ). Cholesterol was determined in the supernate. A correction factor of 1.1 was used to correct the dilution introduced by the precipitating solutions. Lipemic sera with serum triglycerides $>20 \mathrm{mmol} / 1$ were diluted twofold, and those with serum triglycerides $>40 \mathrm{mmol} / 1$ were diluted fourfold. By immunochemical techniques we ascertained that lipoproteins that contain apolipoprotein B were precipitated quantitatively up to a serum triglyceride concentration of $80 \mathrm{mmol} / 1$.

A second precipitating method with heparin- $\mathrm{MnCl}_{2}$ for the HDL separation was simultaneously used for 60 specimens. It was performed as described in the Lipid Research Clinic Program (13).

Cholesterol was measured enzymatically (14). The intra-assay precision of the cholesterol determination was examined with various volumes of the control serum Precilip (Boehringer, Mannheim, West-Germany). The intra-assay and inter-assay precision of the precipitation method was calculated from 20 determinations of a serum pool. The data are mean values \pm SEM. After linear regression analysis with calculation of the slope and the $y$-intercept the significance of the correlation coefficients $(r \pm S D)$ was calculated by the t-test.

\section{Results}

As shown in table 1 , there was a significant correlation between the HDL cholesterol values obtained by preparative ultracentrifugation and by dextran sulfate- $\mathrm{MgCl}_{2}$ precipitation. The slope of the linear regression analysis was 0.98 . The comparison between the dextran- $\mathrm{MgCl}_{2}$ and, furthermore, the heparin- $\mathrm{MnCl}_{2}$ precipitation in 60 specimens showed a significant correlation, with a slope of 1.03 .

The intra-assay coefficient of variation (CV) for the dextran- $\mathrm{MgCl}_{2}$ method was $2.3 \%$. The inter-assay $\mathrm{CV}$ of 20 separate days was $2.7 \%$.

\section{Discussion}

The dextran sulfate- $\mathrm{MgCl}_{2}$ technique with subsequent enzymatic cholesterol assay is highly reproducible; it allows a satisfactory quantification of HDL cholesterol and compares well with preparative ultracentrifugation. In agreement with Kostner (8) we could demonstrate no apolipoprotein B immunoreactivity in the supernatant; this shows that apolipoprotein B-containing lipoproteins are completely precipitated. Lipemic sera must be diluted as proposed for other precipitation methods $(5 ; 7)$. For comparable cholesterol concentrations Finley et al. (9) found a slightly better $\mathrm{CV}(1.7 \%, \mathrm{n}=30)$ for intraassay precision.

There was a good correlation between dextran sulfate$\mathrm{MgCl}_{2}$ and heparin- $\mathrm{MnCl}_{2}$ precipitation for HDL separation. Both methods give comparable results. The heparin$\mathrm{MnCl}_{2}$ method must be performed at $4{ }^{\circ} \mathrm{C}$, while the dextran sulfate- $\mathrm{MgCl}_{2}$ precipitation can be applied at room temperatures. 


\section{References}

1. Rhoads, G. G., Gulbrandsen, Ch. L. \& Kagan, A. (1976) N. Engl. J. Med. 294, 293-298.

2. Miller, N. E., Thelle, D. S., F $\phi r d e$, D. H. \& Mjфs, O. D. (1977) Lancet $I, 965-968$.

3. Gordon, T., Castelli, W. P., Hjortland, M. C., Kannel, W. B. \& Dawber, T. R. (1977) Amer. J. Med. 62, 707-714.

4. Castelli, W. P., Doyle, J. T., Gordon, T., Hames, C. G. Hjortland, M. C., Hulley, S. B., Kagan, A. \& Zukel, W. J. (1977) Circulation 55, 767-769.

5. Lopes-Virella, M. F., Stone, P., Ellis, S. \& Colwell, J. A. (1977) Clin. Chem. 23, 882-884.

6. Albers, J. J., Warnick, G. R., Wiebe, D., King, P., Steiner, P., Smith, L., Breckenridge, C., Chow, A., Kuba, K., Weidmann, S., Arnett, H., Wood, P. \& Shlagenhaft, A. (1978) Clin. Chem. 24 853-856.

7. Schwandt, P. \& Weisweiler, P. (1979) Clin. Chim. Acta, 95, 395-399.
8. Kostner, G. M. (1976) Clin. Chem. 22, 695.

9. Finley, P. R., Schifman, R. B., Williams, J. \& Lichti, D. A. (1978) Clin. Chem. 24, 931-933.

10. Srinivasan, S. R. \& Berenson, G. S. (1977) Clin. Chem. 23, 912-913.

11. Weisweiler, P. \& Schwandt, P. (1977) Klin. Wochenschr. 55, 791-794.

12. Weisweiler, P. \& Schwandt, P. (1978) Atherosclerosis 31 , 53-58.

13. Manual of Laboratory operations. Lipid Research Clin. Program, Vol. I: Lipid and Lipoprotein Analysis (1974). M.S. Department of Health, Education and Welfare, Pub. No. (NIH) 75-628.

14. Röschlau, P., Bernt, E. \& Gruber, W. (1974) J. Clin. Chem. Clin. Biochem. 12, 403-407.

Dr. med. P. Weisweiler Med. Klin. II, Klinikum Großhadern Universität München

Marchioninistr. 15

D-8000 München 70 


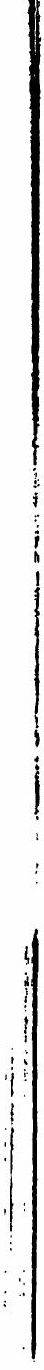

。 